\title{
The Impact of Dissolved Nitrate and Phosphate on Maximum Growth Rate and Carrying Capacity of Oscillatoria in Intensive Shrimp (Litopenaeus vannamei) Farming Pond Situbondo, East Java, Indonesia
}

\author{
Dian Aliviyanti ${ }^{*}{ }^{*}$, Suharjono ${ }^{2}$, Catur Retnaningdyah ${ }^{2}$ \\ ${ }^{1}$ Master Program of Biology, Faculty of Mathematics and Natural Sciences, University of Brawijaya, Malang, Indonesia \\ 2Department of Biology, Faculty of Mathematics and Natural Sciences, University of Brawijaya, Malang, Indonesia
}

\begin{abstract}
The aims of study are to analyze the effect of dissolved nitrate and phosphate content of the intensive shrimp farming pond Situbondo to maximum growth rate and carrying capacity of Oscillatoria population density in the laboratory. This is an experimental research method using completely randomized design with three replications. The treatment were variation of nitrate and phosphate concentration (N0; N6; N12; N24; N48; P0,2; P0,4; P0.8, P1.6 mg. $\mathrm{L}^{-1}$ ). Experiment was done using a pure Oscillatoria culture in condition 25 watt lamp; 12 hours a day. The initial amount of Oscillatoria cells used for the treatment is $8-15 \times 10^{4}$ cell. $\mathrm{mL}^{-1}$. During the incubation process, chemical parameters were also observed including nitrate, phosphate, $\mathrm{DO}$, and $\mathrm{pH}$ at the beginning of the incubation period. Oscillatoria cell was count every day until stationary phase for 30 days. Furthermore, a different test between treatments was conducted to determine levels of nitrate and phosphate in triggering the blooming of Oscillatoria using Oneway ANOVA analysis with SPSS Program. The results showed that the intensive shrimp pond waters of Situbondo already contain dissolved phosphate between $0.4-0.5 \mathrm{mg} \cdot \mathrm{L}^{-1}$. Oscillatoria growth is strongly influenced by dissolved phosphate content in waters, phosphate levels of $0.2-0.4$ or equivalent to the actual level of $0.6-0.7 \mathrm{mg} \cdot \mathrm{L}^{-1}$ can cause the highest abundance of Oscillatoria that could endanger the ecosystem.
\end{abstract}

Keywords: dissolved phosphate, intensive shrimp farming, Nitrate, Oscillatoria.

\section{INTRODUCTION}

Nitrates and phosphates are essential components that determine the primary productivity of the water. Generally, the utilization of nitrates by organisms aims for the formation of biomass, as a component of amino acids, and various proteins from the synthesis [1]. While phosphate is a component of nucleic acid that regulates protein synthesis and transformation of adenosine phosphate as an energy source in intracellular transport [2]. In the intensive shrimp farming pond system, both compounds have been fulfilled on the content of artificial feed that was applied during the cultivation takes place.

Provision of artificial feed to the maximum and continuously expected to spur high shrimp productivity. But over the long period of shrimp cultivation cycle, there has been an increased content of organic matter in the waters. The content of organic materials in the pond ecosystems comprised of dissolved nitrate and phosphate, which is generally derived from shrimp feed residues that were applied during cultivation process

\footnotetext{
* Correspondence address:

Dian Aliviyanti

Email : aliviyantidian@gmail.com

Address : Master Program of Biology, University of Brawijaya, Veteran Malang, Malang 65145
}

[3]. In addition, dirt, shrimp, and plankton dead bodies, can also increase the load of organic matter in the water. The high content of organic matter in the waters can trigger a population explosion of harmful algae [4]. Based on the results of weekly monitoring during the four cultivation cycles in intensive shrimp (Litopenaeus vannamei) farming ponds Situbondo, it is known that Oscillatoria has a high density and susceptible population explosion [5].

Oscillatoria belongs to the non-heterocys Cyanobacteria filamentous group [6]. Generally the group is categorized in harmful algae because it is capable of producing natural biotoxins that negatively affect human and animal health $[7,8]$. The toxic compounds produced by Oscillatoria are microcystins (MCYs), anatoxin-a, anatoxin-a (S), and aplysiatoxins, which attack liver, nerve, and skin tissues [9]. In addition density of Oscillatoria along with Actinomycetes bacteria can produce geosmine and methylisoborneol (MIB) compounds that cause off-flavor odor on shrimp or other aquaculture organisms [10]. The genus is categorized as one type of organic pollutant bioindicator at moderate to high level of organic nutrient [11].

A wide variety of studies suggest a blooming of Cyanobacteria groups in aquatic ecosystems 
may affect ecosystem services, including in pond ecosystems [2,3]. Thus, to keep the water quality of shrimp intensive farms remain in good performance and guarantee a stable shrimp production, control of Oscillatoria population density needs to be done. This study aims to analyze the effect of dissolved nitrate and phosphate content of intensive shrimp farming ponds Situbondo to the maximum growth rate and maximum abundance of Oscillatoria popula-tion density in the laboratory.

\section{MATERIALS AND METHODS}

\section{Sampling and Cultivation of Culture}

Test on nitrate and phosphate concentration was done in Ecology and Microbiology Laboratory of Biology Department, Faculty of Mathematics and Natural Sciences, Brawijaya University, Malang, Indonesia. Pure Oscillatoria culture was obtained from Limnology LIPI (Indonesian Institute of Science), Cibinong.

The research method used laboratory experiment using complete factorial randomized design with three replications to find out the effect of nitrate and phosphate concentration toward the growth rate and carrying capacity of Oscillatoria. The treatments were conduted in the natural media of intensive shrimp farming ponds. The treatments include variations in $\mathrm{N}(0,6,12,24$, $\left.48 \mathrm{mgL}^{-1}\right)$ and $\mathrm{P}\left(0.2,0.4,0.8,1.6 \mathrm{mgL}^{-1}\right)$ concentrations. Natural media used in this experiment were the combination of pond water and shrimp ponds derived from intensive shrimp (Litopenaeus vannamei) farming ponds Klatakan Village, Kendit District, Situbondo Regency, to reach salinity $10 \mathrm{ppt}$. Prior to the application of nitrate and phosphate variations, the natural sterilized growth media was filtered using paper filter. Each treatment of nitrate and phosphate requires natural media of $2 \mathrm{~L}$ pond water, placed on a glass jar size $3 \mathrm{~L}$. The next step is the incubation process in the laboratory using 25 watt lamps, 12 hours a day. Next, the number of Oscillatoria cells were observed every day until the stationary phase for 30 days.

\section{Observation of Chemical Parameter on Oscilla- toria Natural Growth Medium}

Chemical parameter observation was performed on Oscillatoria growth media. Measurements were made on natural growth medium with various variations of nitrate and phosphate concentration with three times repetitions. Water quality parameters observa-tion included nitrate content using Brusin-colorimetric method, phosphate using Stannous chloride- colorimetric method, DO using titri-metric method, and $\mathrm{pH}$ media using potentio-meter method [12].

\section{Number of Oscillatoria Cells}

The number of Oscillatoria cells was determined by sampling procedure $2 \mathrm{~mL}$ aseptically and added methylene blue $0.1 \%$ by two drops and formalin $10 \%$ by one drop into the test tube. The sample then be piped and inserted into the haemocytometer. Observation was done in a microscope with $400 \times$ magnification and calculated the number of Oscillatoria cells contained in a large volume box of $1 \times 10^{4} \mathrm{~cm}^{3}$. Furthermore, the calculated Oscillatoria cell density is entered into the formula below [14].

$\frac{\text { Number of Cell }}{\mathrm{mL}}=\frac{\text { Number of Counted Cells } \times \text { dillution factor }}{1 \times 10^{4} \mathrm{~cm}^{3}}$

\section{Data Analysis}

Data analysis was conducted to know the effect of nitrate and phosphate concentration variation on growth rate of Oscillatoria in the natural media of pond water. Furthermore, growth data of Oscillatoria were analyzed to determine the intrinsic growth rate $(r)$ and environmental carrying capacity $(\mathrm{K})$ that affected the growth of Oscillatoria [14]. From the information then a growth curve were made in order to note the value of nitrate and phosphate concentration that can trigger blooming of Oscillatoria in pond waters. The following formula was used to find the intrinsic growth rate $(r)$ and environmental carrying capacity (K). Further calculation results are tested between treatments to determine levels of nitrate and phosphate which trigger the blooming of Oscillatoria using Oneway Anova analysis with SPSS application for windows Ver.16 [13].

$$
N_{t}=\frac{K}{1+\mathrm{e}^{a-r t}}
$$

Note:

$\mathrm{N}_{\mathrm{t}}$ = population density at a given $\mathrm{t}$ time of population growth

$\mathrm{K}$ = carrying capacity of the environment

$\mathrm{e}=$ natural logarithms (2.71828)

$r=$ inrinsic growth rate

$\mathrm{t}=$ time incubation

\section{RESULT AND DISCUSSION Media Quality}

The observation of chemical parameters on Oscillatoria growth media showed varying values. At this stage, we observed actual content of nitrate and dissolved phosphate, and the level of $\mathrm{DO}$ and $\mathrm{pH}$ growth media at the beginning of the incubation period (Table 1). It is known that the 
pond waters of intensive shrimp pond culture of Situbondo contained dissolved phosphate with levels between $0.4-0.5 \mathrm{mgL}^{-1}$. While the actual nitrate content is ranged from $0.07-0.42 \mathrm{mgL}^{-1}$. The nutrient content of the waters including nitrates and phosphates is generally derived from the residual feed or decomposition process of dirt, shrimp bodies, plankton and bacteria that died during the cultivation. High levels of dissolved phosphate in the waters can lead to population blooms of various types of harmful algae groups [1]. Figure 1 showed that Oscillatoria growth pattern in the treatment of phosphate variation was higher than in nitrate treatment. If it is allowed continously, it will disrupt the balance of the pond ecosystem and affect the productivity and sustainability of the shrimp farming process.

DO concentration of Oscillatoria growth media ranged from 4 - $5 \mathrm{mgL}^{-1}$. In general, the dissolved oxygen content in the water depends on the rate of phytoplankton photosynthesis [15]. The fluctuation of DO value is strongly associated with Oscillatoria growth. It is known that DO levels in phosphate treatment are lower compared to nitrate treatment. This can be happened because the level of oxygen consumption in the waters depends on the biomass load of the organisms that make up the ecosystem [16]. The higher biomass number of organism in an ecosystem making up higher oxygen demand.
The $\mathrm{pH}$ value of the media both in nitrate or phosphate treatment is known to have the same trend, i.e. in the range value of 8 . The stability of the water $\mathrm{pH}$ is strongly influenced by the growth of phytoplankton, in this case related to the utilization of $\mathrm{CO}_{2}$ as material for photosynthesis process. Increased $\mathrm{pH}$ of the waters may be due to $\mathrm{CO}_{2}$ consumption by microalgae characterized by increased levels of DO and chlorophyll- $a$ [16].

\section{Oscillatoria Growth Pattern}

Based on the observation of Oscillatoria growth pattern, it is known that the addition of varied nitrate and phosphate in natural media has been able to support Oscillatoria growth (Fig. 1). In general, it can be seen that the addition of variations in nitrate and phosphate levels showed different responses. The addition of nitrate to natural growth medium is known to cause a slower response to Oscillatoria growth compared to phosphate addition treatment.

The addition of phosphate in the medium is capable of supporting the Oscillatoria growth, but the addition of nitrate without the addition of phosphate is not capable on supporting the maximum growth of Oscillatoria as in Figure 1a. The addition of $0-0.4 \mathrm{mgL}^{-1}$ phosphate levels has been able to cause the highest abundance of Oscillatoria. In addition it is known that the intensive shrimp farming pond Situbondo already contained dissolved phosphate (Table 1). Thus the treatment of nitrate or phosphate can lead to differences in growth patterns of Oscillatoria.

Table 1. Chemical Parameters Observed at the Beginning of the Incubation Period in Natural Media of Oscillatoria Growth

\begin{tabular}{cccc}
\hline Addition treatment & $\begin{array}{c}\text { Actual levels of nitrate } \\
\left(\mathbf{m g L}^{-1}\right)\end{array}$ & $\begin{array}{c}\text { Actual levels of dissolved } \\
\text { phosphate }\left(\mathbf{m g L}^{-1}\right)\end{array}$ & DO $\left(\mathbf{m g L}^{-1}\right)$ \\
\hline N0 & $0.07 \pm 0.07$ & $0.50 \pm 0.07$ & $8.82 \pm 0.30$ \\
P0 & $0 \pm 0$ & $0.61 \pm 0.04$ & $4.89 \pm 0.17$ \\
P0.2 & $0 \pm 0$ & $0.71 \pm 0.04$ & $4.36 \pm 0.66$ \\
P0.4 & $0 \pm 0$ & $0.92 \pm 0.10$ & $4.64 \pm 0.79$ \\
P0.8 & $0.42 \pm 0.72$ & $1.54 \pm 0.05$ & $4.46 \pm 0.68$ \\
P1.6 & & & $8.11 \pm 0.01$ \\
P0 & $0.07 \pm 0.07$ & $0.50 \pm 0.07$ & $8.16 \pm 0.07$ \\
N0 & $6.79 \pm 0.64$ & $0.48 \pm 0.03$ & $5.14 \pm 0.08$ \\
N6 & $10.77 \pm 2.64$ & $0.44 \pm 0.09$ & $5.01 \pm 0.52$ \\
N12 & $30.57 \pm 2.15$ & $0.53 \pm 0.05$ & $8.19 \pm 0.02$ \\
N24 & $59.35 \pm 8.98$ & $0.51 \pm 0.04$ & $8.20 \pm 0.02$ \\
N48 & & & $8.15 \pm 0.02$ \\
\hline
\end{tabular}

Note: Data is average \pm SD $(n=3)$

The presence of nutrients in water bodies especially phosphates can lead to changes in the structure of the phytoplankton community and is usually dominated by the Cyanobacteria group $[6,7,17]$. Phosphate is a major essential component in plankton life [1]. Plankton utilizes phos- phate content as a nucleic acid component that regulates protein synthesis and transforma-tion of adenosine phosphate as an energy source in intracellular transport [2]. Another reason that causes phosphate content in water bodies to be a control in the process of ploriferation on differ- 
ent types of Cyanobacteria groups is the ability of this group in fixing free nitrogen in the air [5]. Algae population explosion usually occurs in warm waters, which can be a distinct advantage

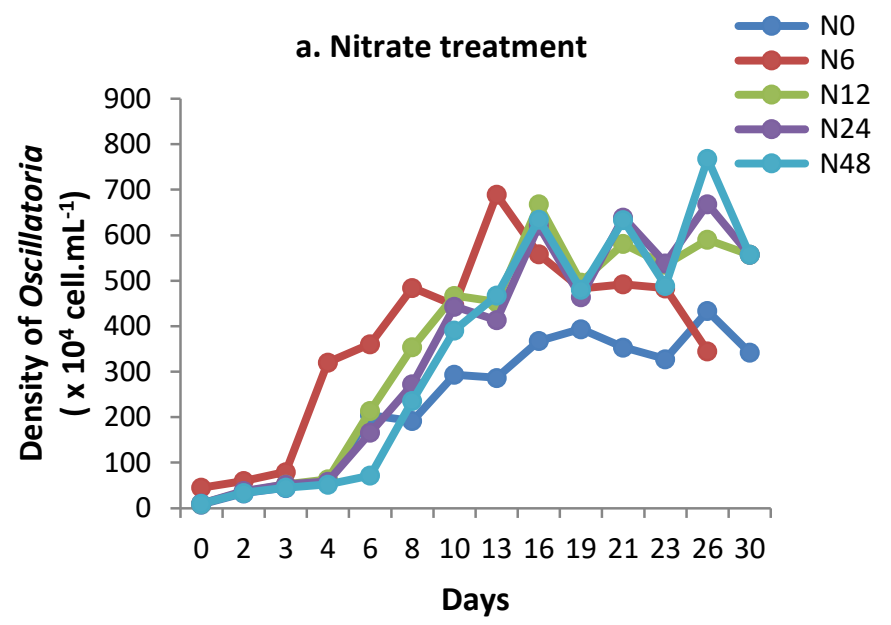

for the group $[6,7,8]$. The concentration level of phosphate absorption by Oscillatoria agardhi capable of supporting maximum growth in waters ranged from 0.2 to $0.3 \mu \mathrm{mol} \mathrm{PL}^{-1}[1]$.

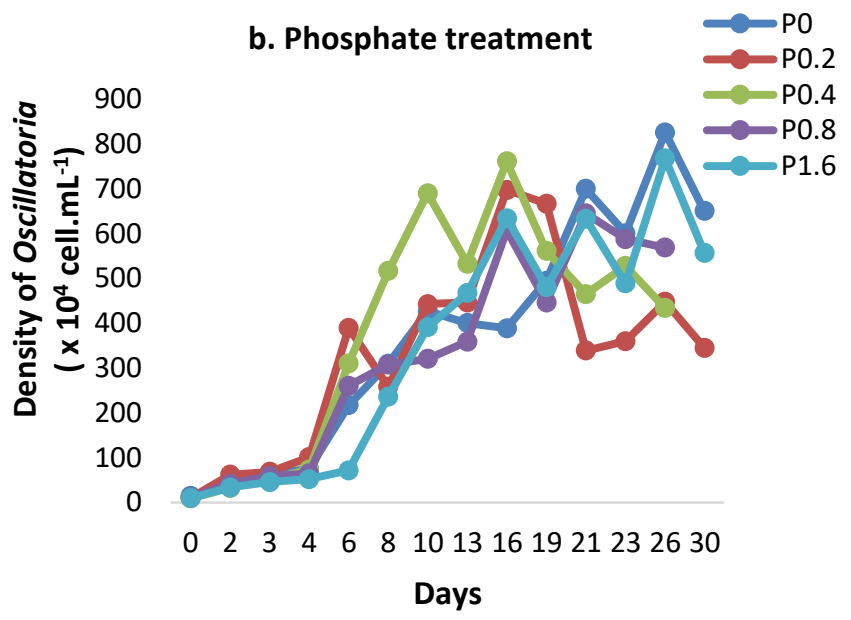

Figure 1. Oscillatoria Growth Pattern on the Treatment Variation of (a) nitrate and (b) phosphate Note: Actual level of nitrate and phosphate was performed in Table 1.

\section{Oscillatoria Carrying Capacity and Growth Rate}

Based on the calculation of Oscillatoria abundance cells for 30 days, then we calculated the intrinsic growth rate $(r)$ and maximum abundance or carrying capacity that can be supported by media (K) at each treatment. The average calculation result of both values can be seen in Figure 2.

Anova test results indicated the growth of Oscillatoria is significantly influenced by phosphate level compared to nitrate. It is reflected from the value of growth rate and maximum abundance that supported by media (Fig 2). Maximum abundance of Oscillatoria has a higher value in the treatments dissolved phosphate levels of 0.2 and $0.4 \mathrm{mgL}^{-1}$ with values between $700-1000$ (x $10^{4}$ cell. $\left.\mathrm{mL}^{-1}\right)$. It is increasingly asserted that Oscillatoria is strongly influenced by the phosphate element. Phosphate is an essential component of ATP that plays a role in various biochemical processes within the cell of organism [18]. In addition, phosphate elements have an important role in cell development and DNA formation [19].

While the variation of nitrate addition on the maximum abundance value of Oscillatoria is in addition of nitrate $0 \mathrm{mgL}^{-1}$ with value $700 \times 10^{4}$ cell. $\mathrm{mL}^{-1}$. It is due to the diazotrophic nature of the organism. The nature of diazotroph is the organism's ability to block free $\mathrm{N}_{2}$ from air [5]. Most members of Cyanobacteria filamentous non-heterocys including Oscillatoria are diazo- troph, thus causing the organism to survive as long as there is still an environmental phosphate element $[5,11]$. It is also related to the actual dissolved phosphate content of the media which has reached $0.5 \mathrm{mgL}^{-1}$, so that the nitrate content of the media can be enriched directly through free $\mathrm{N}_{2}$ fixation from air. The low maximum abundance value on the treatment of other nitrate variations $\left(6,12,24\right.$, and $\left.48 \mathrm{mgL}^{-1}\right)$ corresponds to the optimal $\mathrm{N}: \mathrm{P}$ ratio that is capable of being supported for the microalgae group growth. The optimal N:P ratio that can cause maximum microalgae growth is $1: 15$ [20, 21].

The calculation results of the maximum growth rate of Oscillatoria in phosphate and nitrate addition showed relatively similar fluctuations with result of carrying capacity. In general, variations in the addition of phosphate levels of $0.2-0.4 \mathrm{mgL}^{-1}$ can produce high growth rate values, while the addition of phosphate levels more than that value can not support the increase in maximum Oscillatoria growth rate in the media. The results are consistent with previous studies which reveal the production of $O$. agardhi toxin characterized by addition of biomass depending on low phosphate levels (0.1$0.4 \mathrm{mgL}^{-1}$ ) and elevated phosphate levels do not provide additional effects because they are not supported with sufficient dissolved nitrate content [17]. 
Furthermore, the treatment of nitrate addition $48 \mathrm{mgL}^{-1}$ capable of causing the highest growth rate value. The $\mathrm{N}$ element is one of the essential components of a protein that acts as a biomass-forming cell and plant tissue $[5,21]$. Another important function of the $\mathrm{N}$ element is as an essential biochemical agent such as chlorophyll formation and its role in the process of photosynthesis, formation of various enzymes used for biochemical processes and assimilation of nutrients by organisms, as well as nucleic acid components such as DNA and RNA [1].

The Oscillatoria group is categorized as one type of organic pollutant bioindicator at moderate to high level nutrient organic [10]. The existence of Oscillatoria in pond ecosystems can gradually initiate the growth of other CyanoHABs groups such as Microcystis and Anabaena [2,22]. If it is left continuously it can cause more severe ecosystem damage. So that through the control of Oscillatoria in the pond is expected to become a breakthrough of environmentally friendly habitat management as an early warning system in an effort to maintain water quality during the cultivation process in order to produce a continuous increase in production. a

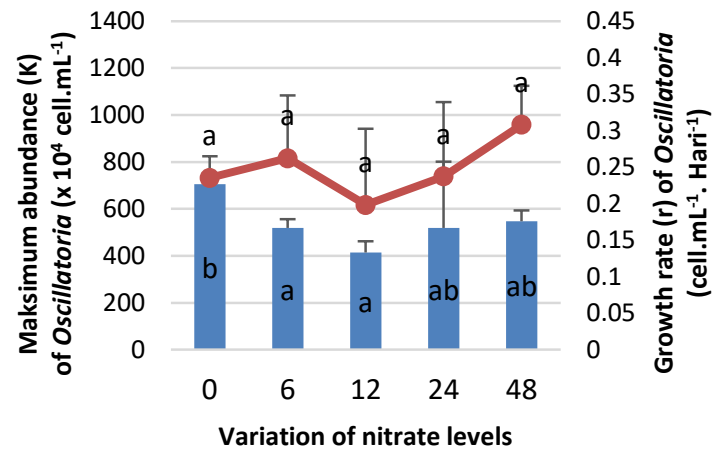

b

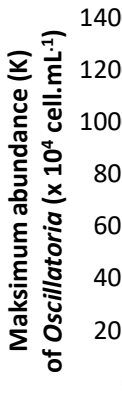

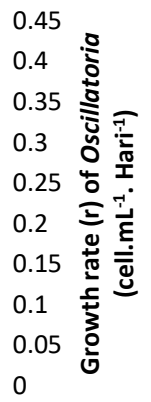

$\begin{array}{lllll}0 & 0.2 & 0.4 & 0.8 & 1.6\end{array}$

Variation of phosphate levels
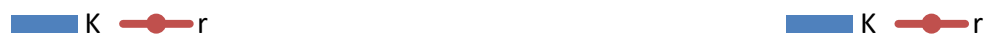

Figure 2. Maximum abundance $(\mathrm{K})$ and growth rate $(\mathrm{r})$ Oscillatoria which can be supported by the treatment of $(\mathrm{a})$ nitrate and (b) phosphate addition in natural media

Note: Notation of treatment of variation of $\mathrm{P}$ on parameter $\mathrm{K}$ showed no significant difference based on Tukey test. $\mathrm{N}$ treatment notation on $\mathrm{N}$ parameter shows no significant difference based on Games-howel test.

\section{CONCLUSION}

Intensive shrimp farming pond Situbondo waters are known to contain nitrate with levels ranged from $0.07-0.42 \mathrm{mgL}^{-1}$ and dissolved phosphate ranged from 0.4 to $0.5 \mathrm{mgL}^{-1}$. The addition of nitrate content in natural media is not able to support the growth of Oscillatoria to its full potential. While the addition of soluble phosphate as much as $0.2-0.4$ or equivalent with the actual content of phosphate $0.6-0.7 \mathrm{mgL}^{-1}$ in natural media able to support Oscillatoria growth maximally.

The results show that maximum abundance or carrying capacity of Oscillatoria is strongly influenced by dissolved phosphate in the water bodies. Thus controlling the population of Oscillatoria in pond waters can be done through the manipulation of habitat by controlling the phosphate content of waters that is not exceeding 0.2 or equivalent to the actual content of phosphate $0.6 \mathrm{mgL}^{-1}$.

\section{ACKNOWLEDGEMENT}

We are thankful to the staffs of Mutiara Mas III shrimp farming pond Situbondo for their valuable helps with field work and collecting samples. This study was sponsored by LPDP thesis research scholarship, Ministry of Finance, Indonesia Government.

\section{REFERENCES}

[1] Reynolds, C.S. 2006. The ecology of phytoplankton. Cambridge University Press. Cambrige.

[2] Davidson, K., R.J. Gowen, P.J. Harrison, L.E. Fleming, P. Hoagland, G. Moschonas. 2014. Anthropogenis nutrients and harmful algae in coastal waters. J. Environ. Manage. 146. 206-216.

[3] Keawtawee, T., K. Fukami, P. Songsangjinda, P. Muangyao. 2012. Nutrient, phytoplankton and harmful algal blooms in the 
shrimp culture ponds in Thailand. Kuroshio Sci. 5-2. 129-136.

[4] Noyma, N.P., L.D. Magalhaes, L.L. Furtado, M. Mucci, F.V. Oosterhout, V.L.M. Huszar, M.M. Marinho, M. Lurling. 2015. Controlling Cyanobacterial blooms through effective flocculation and sedimentation with combined use of flocculants and phosphorus adsorbing natural soil and modified clay. Water Res. 1-13.

[5] Aliviyanti, D., Suharjono, C. Retnaningdyah. 2017. Cyanobacteria dynamics and throphic status of intensive shrimp (Litopenaeus vannamei) farming pond in Situbondo, East Java, Indonesia. J. Trop. Life. Sci. 7(3). 251257.

[6] Issa, A.A., M.H. Abd-Alla, T. Ohyama. 2014. Nitrogen fixing Cyanobacteria: future prospect. Nutrient Management Spear Program. Cornell University.

[7] O'Neil, J.M., T.W. Davis, M.A. Buford, C.J. Gobler. 2012. The rise of harmful cyanobacteria blooms: The potential roles of eutrophication and climate change. Harmful Algae. 14. 313-334.

[8] Wells, M.L., V.L. Trainer, T.J. Smayda, B.S.O. Karlson, C.G. Trick, R.M. Kudela, A. Ishikawa, S. Bernard, A. Wulff, D.M. Anderson, W.P. Cochlan. 2015. Harmful algal blooms and climate change: learning from the past and present to forecast the future. Harmful Algae. 49. 68-93.

[9] Weirich, C.A., T.R. Miller. 2014. Freshwater harmful algal blooms: toxins and children's health. Curr. Probl. Pediatr. Adolesc. Health Care. 44(1). 2-24.

[10] Haryono, S.S. 2001. Off-flavor. Majalah Mitra Bahari Kumpulan Artikel Budidaya. VI(3). 101-104.

[11] Onyema, I.C. 2013. Phytoplankton bioindicators of water quality situations in the lyagbe lagoon, South-western Nigeria. Acta SATECH. 4(2). 93-107.

[12] Clesceri, L.S., A.E. Greenberg, A.D. Eaton. 1998. Standard methods for the examination of water and wastewater, $20^{\text {th }} \mathrm{Ed}$. American Public Health Association. Washington D.C.

[13] SPSS. 2003. Analytical software. Statistical Package for the Social Sciences (SPSS) Headquarters, Chicago, Illinois, USA.

[14] Pianka, E.R. 1974. Factors Affecting Population Growth. Harper and Row Publ. New York.
[15] Makmur, A.I.J. Asaad, Utoyo, A. Mustafa, E.A. Hendrajat, Hasnawi. 2010. Karakteristik kualitas perairan tambak di Kabupaten Pontianak. Research Center of Aquaculture Fisheries in Brackish Water. Proceeding of Aquaculture Innovation Forum. 1165-1171.

[16] Zang, C.S., S. Huang, M. Wu, S. Du, M. Scholz, F. Goo, C. Lin, Y. Guo, Y. Dong. 2011. Comparison of relationships between $\mathrm{pH}$, dissolved oxygen and chlorophyll a for aquaculture and non-aquaculture waters. $W a$ ter Air Soil Pollut. 219. 157-174.

[17] Sivonen, K. 1990. Effect of light, temperature, nitrate, orthophosphate, and bacteria on growth of and hepatotoxin production by Oscillatoria agardhii strains. Appl. Environ. Microbiol. 2(5). 2658-2666.

[18] Hyland, C., Q. Ketterings, D. Dewing, K. Stockin, K. Czymmek, G. Albrecht, L. Geohring. 2005. Phosphorus basics: the phosphorus cycle. Nutrient management Spear Program. Cornell University. Available at: http://nmsp.css.cornell.edu.

[19] Istvànovics, V. 2008. The role of biota in shaping the phosphorus cycle in lakes. Freshwater Rev. 1. 143-174.

[20] Dike, N.I., S.J. Oniye, V.O. Ajibola, A.U. Ezealor. 2010. Nitrate and phosphate levels in river Jakara, Kano state, Nigeria. Sci. J. 5(3). 161-165.

[21] Brown, S. 1999. The nitrogen cycle. University of Washington. USA.

[22] Wu, N., B. Schmalz, N. Fohrer. 2014. Study progress in riverine phytoplankton and its use as bio-indicator - a review. Austin J. Hydrol. 1(1). 9. 